\title{
Influence and Impact of Mosquito-borne Diseases on the History of Florida, USA ${ }^{1}$
}

\author{
Lawrence J. Hribar ${ }^{2}$
}

\begin{abstract}
Mosquito-borne disease has had a significant impact on the history of Florida. Malaria, yellow fever, and dengue are the three most important diseases of humans in the history of the state. Malaria was a leading cause of death among Floridians until the mid 20th Century. Yellow fever was a danger until the last outbreak in 1905. Dengue continues to be a problem in Florida. Other mosquito-borne viruses continue to impact the state in modern times. Still others are potential threats although not present yet. Politics, economics, public perception, and the mass media all influence the control of mosquitoes.
\end{abstract}

Key Words: mosquito-borne diseases, Florida (USA), history

In 2012, when people think of Florida they probably think of the attractions in Orlando; St. Augustine, the oldest city in the United States; the beaches near Panama City, Ft. Lauderdale, and Naples; the quaint neighborhoods in Key West; the nightlife in Miami Beach; and fishing trips from just about anywhere on the coasts. It is only within the last 60 years or so that Florida has become the nation's year round playground. That change came about in large part due to mosquito control (Mulrennan 1986). Until relatively recently, life in Florida was thought to be "unbearable" (Gaiser 1980). Mulrennan (1991) stated flatly that no one came to Florida in the summer prior to the 1950s. An indication of just how bad life could be back then may be gleaned from the following quote by Maurice Provost, first director of what would later become the Florida Medical Entomology Laboratory. "My most vivid memories of malaria-control days in Florida are of the morning-after inspections of so many of the humble shacks we sprayed with DDT. The poor housewife often enough would come to me with tears of joy and show me a basketful of dead bedbugs, roaches, and other vermin, and she would exclaim that her family had spent the first night of their lives without annoyance from biting or creeping things" (Provost 1973).

For many years much of Florida was sparsely inhabited. In 1830, for example, the population of the entire state of Florida was only 34,730 (Cody 2006). By comparison, the population of the City of Lake Worth in 2010 was 34,910. Settlements were restricted to the northern tier of counties near Alabama and Georgia. This part of the State, between Pensacola and Jacksonville, was disease-ridden and poverty stricken and was known as the "malaria belt" (Gaiser 1980). Yellow fever, dengue, cholera, and hookworm were rampant, as were pellagra, influenza, smallpox, diphtheria, pertussis,

\footnotetext{
${ }^{1}$ Submitted on January 24, 2013. Accepted on January 29, 2013.

${ }^{2}$ Florida Keys Mosquito Control District, 503 107th Street, Marathon, Florida 33050 USA. E-mail: lhribar@keysmosquito.org
}

DOI: 10.9784/LEB1(1)Hribar.04 
typhoid, and tetanus. There was a plague outbreak in Pensacola in 1920 (Spencer 1922). Over the years polio became more important, possibly due to the arrival of northern immigrants, and other states would not accept Florida cattle due to tick fever (Bigler 1989).

Mortality from mosquito-borne disease was an ever-present threat. Nancy Hynes DuVal, the wife of the first governor of Florida, died of yellow fever while visiting St. Joseph (now Port St. Joe) in 1841 (Snyder 1993). Naval Surgeon Isaac Hulse, who treated yellow fever victims in Pensacola, lost his 7 year old daughter in the outbreak of 1846 (Pearce 1978). Interestingly enough, Pensacola newspapers downplayed the incidence of disease, believing it would be damaging to the city to report the truth.

\section{A Brief History of Mosquito-Borne Disease in Florida}

Three mosquito-borne diseases have had significant effects on Florida: malaria, yellow fever, and dengue. Malaria was at one time the most important mosquito-borne disease in Florida, causing more illness and death than all other insect-borne diseases combined (Madden 1945). From 1918 to 1924 Florida saw 900 to 1,900 cases of malaria annually, mostly in Lafayette, Levy, Suwannee, and Taylor Counties (Bigler 1989). According to Hodge (1920), Florida's mortality rate for malaria was over 13 times that of other Southern states. In fact, malaria was so prevalent that the Rockefeller Foundation established a malaria research station in Tallahassee (Rockefeller Foundation 1932). During the years 1917 to 1949 deaths from malaria peaked at 429 in 1929, and it was not until 1938 that there were less than 200 deaths reported due to malaria (Lieux 1951). Only in 1948 did the Florida State Board of Health announce that for the first time in Florida's history there were no indigenous cases of malaria (Patterson 2004).

Yellow fever has ravaged the State on numerous occasions. Pensacola had repeated outbreaks; in the 1827 epidemic, Samuel Keep wrote to his brother that $2 / 3$ of the city was " ....sick with a fever which some of the people are too obstinate to call Yellow because it will be a damage to the city..." (Pearce 1978). What has been described as Florida's "worst holocaust" occurred during the yellow fever epidemic of 1877 in Jacksonville and Fernandina Beach. The latter city, with a population of 1,632 had 1,146 ill with yellow fever; there were 24 deaths. Ten years after that, in 1887, Key West, Manatee, Plant City, and Tampa saw yellow fever outbreaks. The following year, in 1888, almost half the population of Jacksonville, $(10,000$ of 26,800) fled the city "in carriages, drays, wagon trains, and ships" (Gaiser 1980). Yellow fever swept through Key West more than once. People who tried to flee the epidemics often were stopped at county lines by armed men who forced refugees to turn back (Diddle 1946). This practice was widespread throughout the southern United States and was known as a "shotgun quarantine". During the 1899 yellow fever epidemic in Miami there were 220 known cases, $13 \%$ of the city's population was infected; 
there were 14 fatalities, a $6.4 \%$ mortality rate. The city was quarantined and guards armed with shotguns enforced the quarantine order. Detention camps were built for persons believed to be infected but not yet showing symptoms (Straight 1995). People certified as immune to yellow fever were issued cards that permitted them to cross quarantine lines during outbreaks (Pearce 1978, Straight 1995).

The 1899 outbreak of yellow fever in Miami is interesting both for what was done and what was not done. Dorn (1949) recalls that a friend of his was the first patient diagnosed with yellow fever. He also states that the yellow fever epidemic came to Miami from Cuba via a boat. Carson (1956) corroborates this in her recounting of the testimony of a Dr. James M. Jackson who said that yellow fever was introduced into Miami by the cattle steamer Laura arriving from Neuvitas [sic], Cuba. The sternwheeler Saint Lucie was turned into a floating quarantine facility; after ten days the boat was permitted to leave Miami and about 200 people fled the city (Dorn 1949, Carson 1956). Houses were fumigated or burned down. Outgoing mail was fumigated. This was before the viral origin of yellow fever and the vectorial role of Aedes aegypti were known. A more interesting tidbit hidden in the description of the outbreak is mentioned by Straight (1955). In July a case of dengue fever was diagnosed in Miami; it was not reported in the newspaper in order not to panic the public who might think yellow fever had returned. The people's fear of yellow fever may have been for more than just the disease itself. Dorn (1949), Straight (1955), and Pearce (1978) all describe treatments that physicians of the time prescribed for yellow fever. They included bloodletting, dosing with calomel and castor oil (and other laxatives and purgatives), blistering, and enemas (sometimes with turpentine and whiskey). At least one patient in the Miami outbreak had his feet placed into hot water, his throat packed in ice, a mustard plaster applied to his chest, and watermelon seed tea forced down his gullet. It is small wonder that 200 people fled the city.

The last outbreak of yellow fever in the United States occurred in 1905 in Pensacola, New Orleans, and a few other towns on the Gulf of Mexico, including West Tampa in Florida (Porter 1906, Patterson 1992). The yellow fever virus apparently was introduced into Florida from Louisiana by vacationers returning from a visit to New Orleans (Porter 1906). The fight against this outbreak was a triumph of mosquito control. Crews went through the city, screening houses and fumigating them with pyrethrum. Suspected mosquito larval habitats were destroyed and citizens slept under bed nets. Interestingly enough, one medical doctor, James S. Herron, refused to allow his house to be inspected. He claimed right of refusal was given him under the United States Constitution. He was fined $\$ 25.00$ for his troubles (Vickers and Vickers 1974).

Dengue likely became distributed worldwide in the $18^{\text {th }}$ and $19^{\text {th }}$ Centuries when international shipping was entering an expansion phase (Gubler 1997). 
Findlay (1946) warned that modern transportation was going to facilitate the spread of disease worldwide. MacKenzie et al. (2004) also warned about the spread of viral diseases via modern transportation. Dengue spread in the past 30 years has been in part due to international travel (Gubler 1989, Wilder-Smith and Gubler 2008).

It is unknown when dengue first arrived in Florida. There were reports of a dengue-like illness in the French West Indies as far back as the late 1700s (Gubler 1997). Dengue was reported in South Florida in 1903 at Ft. Jefferson in the Dry Tortugas and in 1904 and 1908 from Miami (Anonymous 1903, 1904, 1908a, 1908b). These reports were made by Acting Assistant Surgeon Jackson, perhaps the same man who testified regarding the 1899 Miami yellow fever outbreak. Other outbreaks were those in 1905 in Key West, Jacksonville, Miami, and Tampa, totaling about 11,700 cases; and a 1907 outbreak in Hillsborough County. An early mosquito control effort in Miami in 1922 was directly related to the statewide 1921 dengue outbreak that resulted in 82,681 reported cases and 69 deaths (Madden 1945).

The 1934 dengue epidemic was the last outbreak of locally transmitted dengue in Florida until the $21^{\text {st }}$ Century. The epidemic actually was far more widespread than believed; although commonly thought to have been confined to Miami and Tampa, 31 counties reported dengue cases, including 70 cities, towns, and unincorporated villages, for a total of 1,671 cases in Florida (Griffiths 1935). That same year an outbreak occurred in Savannah, Georgia (Griffiths and Hanson 1936). Almost 500 cases had been reported in Georgia by the $20^{\text {th }}$ of October 1934 (Anonymous 1934b). Also in that same year dengue cases were reported from South Carolina and Texas (Anonymous 1934a). During the 1934 dengue epidemic in Miami, 1,500 patients were treated; the director of Dade County Mosquito Control, Fred Stutz, estimated that $10 \%$ of the population had the disease (McCurdy 1963). According to MacDonnell (1935), city officials were at first reluctant to inform the public about dengue but later relented. The Cities of Coral Gables and Miami Beach organized their own anti-dengue campaigns alongside that of the City of Miami. However, delays in implementing anti-mosquito work may have allowed the epidemic to spread to other areas of the State. By the time workers were trained and deployed it was too late to contain the outbreak (Hanson 1936a). Among the more interesting data recorded by the anti-dengue workers in Miami was the fact that automobile tires served as one of the most common habitats for larval Aedes aegypti (MacDonnell 1935). The source of the 1934 dengue epidemic is not known for certain. Ehrenkranz et al. (1971) stated that US troops stationed in Haiti until August of 1934 may have been transported to Miami; however, the epidemic started in July. MacDonnell (1935) believed that a previous outbreak in Mississippi in June of 1934 may have been the source of the Florida epidemic. 
MacDonnell (1935) reported that there may have been as many as 15,000 dengue cases in Miami during the epidemic. Carney (1946) gives the population of Miami as 142,955 at the 1930 census; he then gives a figure of 180,998 for 1935. Interpolation provides an estimated population of 173,389 in 1934. If the 15,000 cases figure is correct and if the interpolated population number is a reasonable estimate, then there was an infection rate of $8.65 \%$ in Miami at that time. According to MacDonnell (1935) dengue was epidemic from July until October. Examination of his data reveals two very interesting facts: 1, there was a steady decrease in positive containers being found by inspectors; and 2, even at the end of the epidemic the level of infestation was unacceptably high (Figure 1). During the same epidemic, Tampa had a 2\% container index (Griffitts and Hanson 1936). Evidently even this low level of infestation was sufficient to support transmission of dengue.

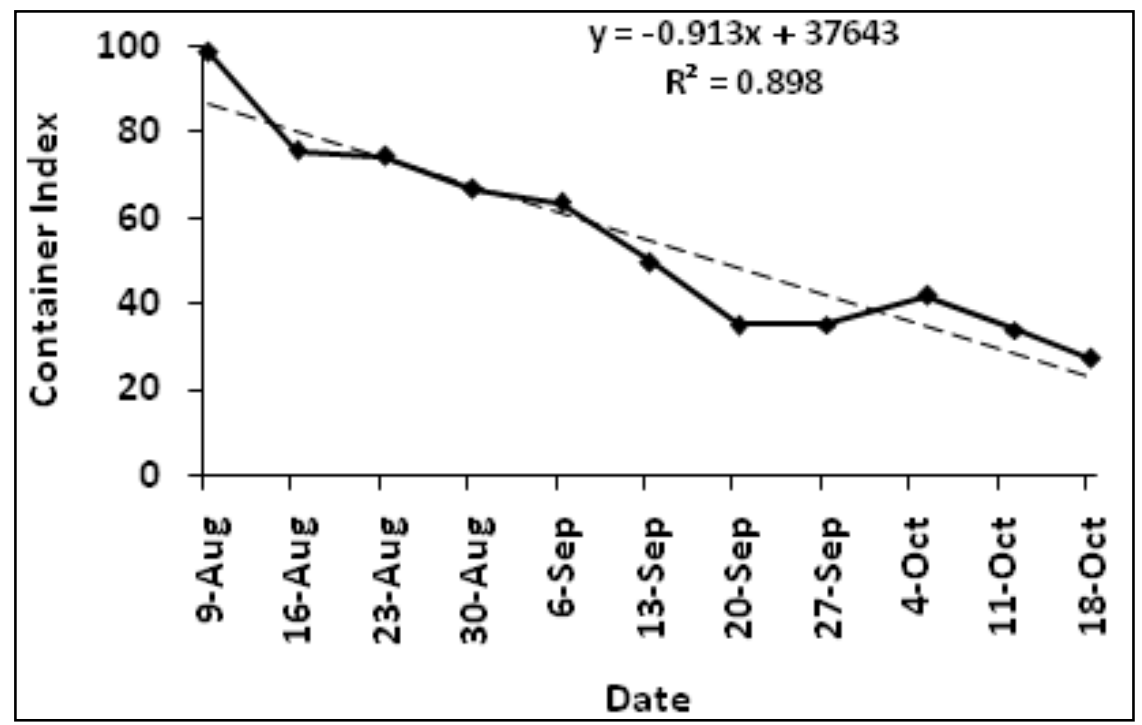

Figure 1. Weekly container indices in the City of Miami during the 1934 dengue epidemic calculated from data provided by MacDonnell (1935).

In the wake of the 1934 outbreak, Hanson (1936b) observed that dengue appeared to require a lower level of infestation by Aedes aegypti than did yellow fever for transmission to occur. It has been difficult for entomologists and epidemiologists to calculate epidemiologically significant indices for dengue transmission (Scott and Morrison 2004). Work done on yellow fever transmission in Latin America indicates that container indices below 10 and house indices below 5 were necessary to prevent transmission (Connor and Monroe 1923, Soper 1967). More recently, workers in Cuba have suggested that Breteau indices below 4 may be the threshold (Sanchez et al. 2006). 


\section{An Ancient Enemy Poses a New Threat: Aedes aegypti and Dengue in Key West}

The success of mosquito control in the fight against mosquito-borne diseases and pest mosquitoes is an outstanding achievement. Unfortunately, this success has led many to think that mosquitoes no longer pose a threat to public health. Twenty one years ago Mulrennan (1991) responded to accusations that the threat of disease is exaggerated by mosquito control officials in order to justify jobs. He pointed out that in the 1990 St. Louis Encephalitis outbreak in Florida 213 human cases were confirmed and 11 people died. Mulrennan warned people that the threat of disease was real and was growing. $\mathrm{He}$ specifically mentioned dengue in the Caribbean. Gill et al. (2000) alerted us that risk of autochthonous transmission of dengue was increasing and that dengue was being imported into Florida at rates much higher than previously suspected. Less than a decade later we saw the first outbreak of locally transmitted dengue in Florida in 80 years. The virus was identified as Dengue serotype 1 of a Nicaraguan strain (Graham et al. 2011). The Key West outbreak serosurvey revealed that $5 \%$ of the population was infected with Dengue 1 virus; some people had previous infections with other serotypes (Radke et al. 2012).

\section{Underreporting of Dengue}

As far back in time as 1936, Hanson (1936a) estimated that the ratio of reported to unreported cases may be as high as 1 to 10 . Investigators in several countries have determined that dengue is routinely underreported (Rigau-Pérez 1999, Chairulfatah et al. 2001, Duarte and França 2006). There are political and economic disincentives to reporting dengue (Suaya et al. 2007). Furthermore, dengue is not often a medical priority, since social, economic, and environmental issues are given greater emphasis (Gómez-Dantés and Willoquet 2009). There may be complacency toward vector-borne diseases (Gubler 2002). There is no reason to believe that dengue was not underreported in Key West.

The end of an epidemic of dengue is not necessarily the end of the problem. Weller (1983) described the situation in Cuba in the late 1970s and early 1980s. Cuba experienced a Dengue 1 epidemic in 1977-78 in which 553,000 cases were reported. The epidemic waned over the following years but in 1981 a new outbreak of dengue struck the island. This time it was Dengue 2. Cuba saw 344,000 cases and more alarmingly, 158 deaths due to dengue hemorrhagic fever (DHF). The first dengue infection is very often a mild fever; infection by a second serotype can result in a more severe reaction, including DHF (GómezDantés and Willoquet 2009). The fact that all four dengue serotypes are circulating in the Caribbean should give us pause (Guzman and Kouri 2003).

\section{Mosquitoes Affect the Economy of the State}

Mosquitoes were one of several factors that inhibited settlement of the Everglades in the early 1900s (Dovell 1948, Will 1968). The construction of the 
Overseas Railroad from Miami to Key West may have been hindered in part by mosquitoes (Harper 1912). Unfortunately for Florida, as land was developed for housing it oftentimes was done without regard for suitability of the surrounding environment (Stroud and Self 2007). This resulted in a large number of manmade, essentially "do it yourself", mosquito problems for future residents.

Among the benefits of mosquito control to the State are protection of human health, protection of the health of pets and other domestic animals, and increased worker productivity; in heavily infested areas worker productivity can fall to near zero (Williams 1986). It was common in South Florida in the early days of settlement to see people carrying smudge pots to ward off biting insects (Dorn 1949, Viele 1996, Gillis 2009). Agricultural workers often donned veils to avoid the massive clouds of mosquitoes (Viele 1996). People in Miami attended church services carrying smudge pots and switches to chase away mosquitoes (Dorn 1949). Blanche and Hamilton Foreman, pioneers in the Davie area, tried to establish a dairy but had terrible problems with mosquitoes and other biting flies; Seminoles and settlers alike lost livestock due to mosquitoes and horse flies (Gillis 2009).

Very early on, people realized that the seasonal decline in mosquito numbers was partly responsible for the development of the winter tourist trade (Vanderblue 1927). No less a person than Governor Dan McCarty addressed the Florida Legislature to call to their attention the importance of mosquito control to the economy of the State (Mulrennan 1954).

In the 1970s oil embargoes caused the USA to experience gasoline shortages that prompted rationing in some areas (often by use of an odd-even plate number system). In 1979, despite the difficulty of purchasing gasoline, 35 million people visited Florida and spent almost $\$ 16$ billion. In January of 1980 the Florida travel industry sold $\$ 100$ million of international business in two days (Gaiser 1980).

The First World War marked the beginning of Florida's campaign against malaria. In 1917, Army Surgeon General William Crawford Gorgas asked Joseph Porter, who served as Florida's first State Health Officer, to direct the first anti-malaria activities in Florida at Camp Johnson, near Jacksonville (Patterson 2000). The first civilian malaria control efforts in Florida were a cooperative effort among Taylor County, The City of Perry, and the Burton Swartz Cypress Company (Mulrennan and Sowder 1954, Bigler 1989). The success in Perry contributed to a campaign that culminated in 1925 with the passage of legislation allowing the formation of mosquito control districts. The first mosquito control district organized in Florida was that in Indian River County in 1925 (Mulrennan and Sowder 1954). Broward and Dade Counties formed their programs in the 1930s, and after the Second World War mosquito control came into its own in Florida, largely because of the availability of State funds. There are now mosquito control programs in 50 of Florida's 67 counties. 
Mulrennan (1991) pointed out that it is difficult to assess the economic benefit of mosquito control. We have no way of knowing who would have been affected by disease had there been no mosquito control. Mulrennan did mention that during the last quarter of 1990, coincident with the 1990 SLE outbreak, business in Florida declined about $15 \%$. He asked a very good question, "What did the epidemic cost?" We know that mosquito control spent an additional \$2 million statewide during the epidemic. How much was spent for health care for those 213 people taken ill? And what price do you put on 11 lives? We have some answers due to recent research and the news isn't good. The West Nile outbreak in Louisiana in $2002-2003$ cost $\$ 20.1$ million (Zohrabian et al. 2004). Another West Nile outbreak, this one in Sacramento, California in 2005, cost $\$ 2.98$ million (Barber et al. 2010). Lifetime care for one child who survives a severe EEE infection can exceed \$3 million. Even a mild case can cost $\$ 21,000$ (Villari et al. 1995). Non-fatal dengue is responsible for staggering economic losses due to nonproductivity of sick workers (Shepard et al. 2011). Add in loss of school days, loss of tourism, and the costs of medical care of patients and vector control activities and an outbreak can easily cost into the millions of dollars (Gubler 2002).

\section{Public Perception of Mosquito Control Changes through the Years}

Harden (1981) wrote about the situation in Florida prior to mass development and the population boom. In Harden's youth Florida had a population of about 2 million. In 1981, when his article was published, the State had a population of about 9.7 million. The 2010 census put Florida's population at 18,801,310 (US Census Bureau 2010). Harden wrote of all those people, "Only a miniscule number of those millions have the remotest idea of what a mosquito problem can be, or was at one time, in this state. Thus, the mosquito workers are made the villains who have destroyed or adversely affected, our entire estuarine resource and who have, somehow, poisoned much of our surface water. That may not be a true statement, but it is a truism to a large number of Florida citizens who may be dealing with half facts." Viele (1996), in his history of the Florida Keys, pointed out, "Modern residents and visitors are connected to the mainland by highway, pipeline, and electric umbilical cords and insulated from the realities of the Keys environment by air conditioners and mosquito sprays." Viele (1996) quoted a resident who described the mosquito populations on Lower Sugarloaf Key: “...you could rake the mosquitoes off your arms in piles." As an aside, mosquito control is not the only facet of modern Florida life to suffer scorn and disdain. Arsenault (1984) quotes a native-born Floridian woman as saying, "I hate air conditioning; it's a damnfool invention of the Yankees. If they don't like it hot, they can move back up North where they belong." Harden (1981) also wrote, "Florida would not be where it is today were it not for mosquito control. That alone makes a lot of people mad, but they weren't around when you could not go outside after dark and most of 
the coastal communities closed down during the summer. Most of the people who fight your programs are newcomers. A newcomer is now somebody who came here after 1970."

\section{What Next?}

The appearance of dengue in Florida after so many years may be a warning that more and larger outbreaks are in the future (Hotez 2011). Furthermore, the dengue situation in the Americas as a whole is worsening, and the epidemiologic picture now resembles that of Southeast Asia (Guzman and Kouri 2003). Efforts to defund mosquito control programs, and research on mosquitoes and mosquito-borne diseases are shortsighted and put the public health into jeopardy. When West Nile virus turned up in New York City, there was no longer any mosquito control capability, nor anyone on staff that could identify mosquitoes. They had to rely on the Federal government and private contractors for mosquito control (Edman 2004).

Some battles never end. Not only are we struggling against mosquitoes and disease, but we are also fighting the same old wars with politicians of every level. In 1986, Williams (1986) lamented the challenges mosquito control was facing in that era: budget reductions, changes in staff, and regulatory processes being forced upon programs. How many of those are programs facing today? Thomas (1981) may have said it best. "As you know, sometimes we win in Tallahassee and sometimes we lose."

Without population-based programs and political commitment, the dengue problem cannot be solved (Gómez-Dantés and Willoquet 2009). Yet effectiveness of community involvement is difficult to measure and a recent analysis of 11 studies indicated that evidence for effectiveness of communitybased control efforts is weak (Heintze et al. 2007). Nevertheless, other studies utilizing newer methods demonstrated that community-based control programs are effective in reducing Aedes aegypti populations, at least in Cuba (Vanlerberge et al. 2009, Toledo et al. 2011). Of course, Cuba has some social and political characteristics that make it unique among American countries (Gubler 1989).

News media are important vehicles for informing people and for influencing their decisions (França et al. 2004). Gubler (2004) wrote that an outbreak of urbanized yellow fever in modern times would create panic and overreaction in the public, heath officials, and the press. Based on previous history, however, it is more likely that the problem would be glossed over or even denied until the situation was out of control. One example is the 1846 yellow fever epidemic in Pensacola, in which Pensacola newspapers downplayed the incidence of disease, believing it would be damaging to the city to report the truth (Pearce 1978). Again, during the 1899 yellow fever outbreak in Miami a case of dengue fever was diagnosed in July of that year after the yellow fever had abated; it was not reported in the newspaper in order not to 
panic the public who might think yellow fever had returned (Straight 1955). According to MacDonnell (1935), during the dengue epidemic in Miami city officials were at first reluctant to inform the public about dengue but later relented. This kind of thinking is not unique to Florida. Patterson (2009) reported on William Herms' efforts to create mosquito control programs in California. The Governor of California who signed a mosquito control bill did so not out of concern for the health of rural residents but because of pressure from the real estate lobby; their members could not sell mosquito infested properties.

Politics and economics are as important to control of Aedes aegypti as is biomedical knowledge (Slosek 1986). The question is how to convince policymakers and the public that their cooperation in the present will obviate the need to deal with epidemics in the future (Kyle and Harris 2008). Vector control efforts can be hindered or even negated by accumulations of nondegradable containers in yards, inadequate or minimal community participation in control efforts, and lack of access to properties by public health or vector control personnel (Eisen et al. 2009). An entire generation exists that expects government mosquito control efforts on the citizens' own property and criticizes governments for a disease that exists in large part due to the citizens' refusal to clean up their own yards (Gubler 1989). In fact, we are dealing now with multiple generations that expect government to do it all. Mosquito control agencies' use of adulticides for control of Aedes aegypti may create a false sense of security in the public, who may then abdicate their responsibility to clean up their own properties (Espinoza-Gómez et al. 2002). It is a sad fact of life that "key premises" exist, houses that remain consistently infested with Aedes aegypti and serve as foci for reinfestation of neighborhoods (Chadee 2004). The ultimate responsibility for control of Aedes aegypti lies with the property owner (Gubler 1989). Nevertheless, there is an important role for government to play, and that is in the realm of enforcement of ordinances and laws enacted for the control of mosquitoes. Under Florida law, interference with a mosquito control operation or destruction of mosquito control equipment or works is a crime; a second degree misdemeanor punishable by not more than 60 days imprisonment or a fine not to exceed $\$ 500.00$. Political will is needed to make the hard decisions (Guzman and Kouri 2002). Control of Aedes aegypti requires money and personnel and may well present our politicians with a choice between reinfestation and reelection.

In these economically uncertain times, we must ask ourselves one important question: Is it too expensive to control Aedes aegypti? Equipment, training, pesticides, and people cost money. To do the job right, a lot of time must be devoted to seeking out larval habitats and eliminating them. Adult emergences must be dealt with promptly. The public must cooperate with public health and mosquito control agencies in the fight against Aedes aegypti. Whatever the cost, 
surely it will be less than the hospitalization, medicines, lost wages, and funeral expenses that may be the alternative (Gratz 1993).

Other mosquito-borne viruses and their vectors also require attention and surveillance. Venezuelan equine encephalitis virus has caused human and equine illness in Florida, and the virus has been isolated from a number of common Florida mosquitoes (Sudia et al. 1969, Groot 1972). Some of these potential vector species are Culex (Melanoconion) species, which are very difficult to identify as adult females and for which few effective control measures exist. West Nile virus and St. Louis encephalitis are transmitted by Culex quinquefasciatus and Culex nigripalpus, both very common mosquitoes in Florida and frequently found near human habitation. The transmission of these viruses is dependent upon complex meteorological and hydrological cycles which we are only now beginning to understand (Shaman et al. 2004, Day and Shaman 2008). The State of Florida relies to a large extent on data collected by local mosquito control programs and departments of health for surveillance of mosquito-borne viruses. Additionally, the State depends heavily upon the local mosquito control programs to respond to threats posed by outbreaks of mosquito-borne disease. Much of the preceding discussion of the politics of dengue control is applicable to other mosquito-borne viruses in Florida.

In the past 20 years in Florida we have seen outbreaks of St. Louis Encephalitis, West Nile Encephalitis, Eastern Equine Encephalitis, dengue, and malaria. Other mosquito-borne viruses have been detected in Florida, including California encephalitis (Pond et al. 1966). Sometimes we do not even know the viruses are present until after the fact. Ehrenkranz et al. (1963) described a small outbreak of SLE or other similar disease in Miami in 1958 based on serology of patients. When sera were drawn from Seminoles in South Florida, antibodies to Venezuelan Equine Encephalitis were detected (Work 1964). Elsewhere, Chikungunya, Usutu, Rift Valley Fever, and Japanese encephalitis viruses have moved beyond their normal geographic ranges. What is stopping them from coming here? And lest we forget, where there is Aedes aegypti, there can be yellow fever. The world has limited stockpiles of vaccine and is unable to produce mass quantities on short notice (Roukens and Visser 2008). Should urbanized yellow fever become a reality it would be a catastrophe beyond our most lurid fantasies. It was 69 years ago that F.C. Evans (1943) wrote these stunning words: "The ancient resource to prayers and holy water and the more modern use of traps and poisons have two features in common - they always work and they never prevent the next outbreak!" The accuracy of this statement is debatable. What is certain is that mosquito control has made a significant contribution to the public's welfare. It is equally certain that it takes a commitment of funds and other resources to sustain this effort. It takes the resolve and the will of scientists, technicians, public health workers, and mosquito control workers to do what needs to be done to reduce the threat of 
mosquito-borne diseases; and it takes citizens and political leaders who take the threat of mosquito-borne disease seriously.

\section{Acknowledgment}

Dr. Gordon M. Patterson, Professor of Humanities and Communication in Florida Institute of Technology, Melbourne, Florida, read the manuscript several times and offered numerous constructive criticisms, comments, and suggestions that immeasurably improved the paper.

\section{Literature Cited}

Anonymous. 1903. Dengue reported at Fort Jefferson, Dry Tortugas, Florida. Public Health Reports 18:1540.

Anonymous. 1904. Dengue at Miami, Florida. Public Health Reports 19:2192.

Anonymous. 1908a. Report from Miami, Florida Dengue fever present. Public Health Reports 23:1372.

Anonymous. 1908b. Report from Miami, Florida Dengue fever present. Public Health Reports 23:1604.

Anonymous. 1934a. Summary of monthly reports from states. Public Health Reports 49:1318-1319.

Anonymous. 1934b. Dengue in southeastern states. Public Health Reports 49:1319-1320.

Arsenault, R. 1984. The end of the long hot summer: the air conditioner and Southern culture. The Journal of Southern History 50:597-628. http://dx.doi.org/10.2307/2208474

Barber, L. M., J. J. Schleier III, and R.K.D. Peterson. 2010. Economic cost analysis of West Nile virus outbreak, Sacramento, California, USA. 2005. Emerging Infectious Diseases 16:480-486. http://dx.doi.org/10.3201/eid1603.090667

Bigler, W. J. 1989. Public health in Florida - yesteryear. Florida Journal of Public Health 1:7-19.

Carney, J. J. 1946. Population growth in Miami and Dade County, Florida. Tequesta 6:50-55.

Carson, R. L. 1956. Miami: 1896 to 1900. Tequesta 16:3-13.

Chadee, D. D. 2004. Key premises, a guide to Aedes aegypti (Diptera: Culicidae) surveillance and control. Bulletin of Entomological Research 94:201-207. http://dx.doi.org/10.1079/BER2004297

Chairulfatah, A., D. Setiabbudi, R. Agoes, M. van Sprundel, and R. Colebunders. 2001. Hospital based clinical surveillance for dengue haemorrhagic fever in Bandung, Indonesia 1994-1995. Acta Tropica 80:111-115. http://dx.doi.org/10.1016/S0001-706X(01)00180-2

Cody, S. K. 2006. Florida's population center migrates through history. Florida Focus 2(1):1-5.

Conner, M. E. and W. M. Monroe. 1923. Stegomyia indices and their value in yellow fever control. American Journal of Tropical Medicine 4:9-19.

Day, J. F. and J. Shaman. 2008. Using hydrologic conditions to forecast the risk of focal and epidemic arboviral transmission in peninsular Florida. Journal of Medical Entomology 45:458465. http://dx.doi.org/10.1603/0022-2585(2008)45[458:UHCTFT]2.0.CO;2

Diddle, A. W. 1946. Medical events in the history of Key West. Tequesta 6:14-37.

Dorn, J. K. 1949. Recollections of early Miami. Tequesta 9:43-59.

Dovell, J. E. 1948. The Everglades, a Florida frontier. Agricultural History 22:187-197.

Duarte, H. H. and E. B. França. 2006. Qualidade dos dados da vigilância epidemiológica da dengue em Belo Horizonte, MG. Revista de Saúde Pública 40:134-142. http://dx.doi.org/10.1590/S0034-89102006000100021

Edman, J. D. 2004. Battling West Nile virus and other mosquito-borne diseases: a tribute to Dr. Maurice W. Provost. Florida Entomologist 87:412-416. http://dx.doi.org/10.1653/00154040(2004)087[0412:BWNVAO]2.0.CO;2

Ehrenkranz, N. J., W. L. Pond, R. M. Pennington, and M. J. Carter. 1963. Arthropod-borne virus disease in Florida. American Journal of Medicine 35:673-681. http://dx.doi.org/10.1016/00029343(63)90138-4

Ehrenkranz, N. J., A. K. Ventura, R. R. Cuadrado, W. L. Pond, and J. E. Porter. 1971. Pandemic dengue in Caribbean countries and the Southern U.S. - past, present and potential problems. New England Journal of Medicine 285:1460-1469. http://dx.doi.org/10.1056/NEJM197112232852606 
Eisen, L., B. J. Beaty, A. C. Morrison, and T. W. Scott. 2009. Proactive vector control strategies and improved monitoring and evaluation practices for dengue prevention. Journal of Medical Entomology 46:1245-1255. http://dx.doi.org/10.1603/033.046.0601

Espinosa-Gómez, F., R. Coll-Cardénas, and C. M. Hernández-Suárez. 2002. Educational campaign versus malathion spraying for the control of Aedes aegypti in Colima, Mexico. Journal of Epidemiology and Community Health 56:148-152. http://dx.doi.org/10.1136/jech.56.2.148

Evans, F. C. 1943. Review. Voles, mice and lemmings: Problems in population dynamics. Journal of Wildlife Management 7:238-240. http://dx.doi.org/10.2307/3795737

Findlay, G. M. 1946. The internal combustion engine and the spread of disease. British Medical Journal 2:979-982. http://dx.doi.org/10.1136/bmj.2.4486.979

França, E., D. Abreu, and M. Siquiera. 2004. Epidemias de dengue e divulgação de informações pela imprensa. Cadernos de Saúde Pública 20:1334-1341. http://dx.doi.org/10.1590/S0102$\underline{311 \times 2004000500028}$

Gaiser, D. 1980. The importance of mosquito control to tourism in Florida. Proceedings of the Florida Anti-Mosquito Association 51:7-8.

Gill, J., L. M. Stark, and G. G. Clark. 2000. Dengue surveillance in Florida, 1997-98. Emerging Infectious Diseases 6:30-34.

Gillis, S. 2009. Getting the bugs out: Ft. Lauderdale before pest control. Broward Legacy 29:2-3.

Gómez-Dantés, H. and J. R. Willoquet. 2009. Dengue in the Americas: challenges for prevention and control. Cadernos de Saúde Pública 25 Supplement 1:S19-S31.

Graham, A. S., C. A. Pruszynski, L. J. Hribar, D. J. DeMay, A. N. Tambasco, A. E. Hartley, E. M. Fussell, S. F. Michael, and S. Isern. 2011. Mosquito-associated dengue virus, Key West, Florida, USA, 2011. Emerging Infectious Diseases 17:2074-2075. http://dx.doi.org/10.3201/eid1711.110419

Gratz, N. G. 1993. What must we do to effectively control Aedes aegypti? Tropical Medicine 35:243-251.

Griffitts, T. H. D. 1935. Dengue in Florida, 1934, and its significance. Journal of the Florida Medical Association 21:395-397.

Griffitts, T. H. D. and H. Hanson. 1936. Significance of an epidemic of dengue. Journal of the American Medical Association 107:1107-1109. http://dx.doi.org/10.1001/jama.1936.02770400019005

Groot, H. 1972. The health and economic impact of Venezuelan equine encephalitis. pp. 7-16. In, Venezuelan Equine Encephalitis: Proceedings of the Workshop-Symposium on Venezuelan Equine Encephalitis, Washington, DC, 14-17 September 1971. Pan American Sanitary Bureau Scientific Publication No. 243. 416 pp.

Gubler, D. J. 1989. Aedes aegypti and Aedes aegypti-borne disease control in the 1990s: top down or bottom up. American Journal of Tropical Medicine and Hygiene 40:571-578,

Gubler, D. J. 1997. Dengue and dengue hemorrhagic fever; its history and resurgence as a global public health problem. pp. 1-22. In, Gubler, D. J. and G. Kuno (Editors). Dengue and Dengue Hemorrhagic Fever. CAB International Press. Wallingford, Oxon, UK. 478 pp.

Gubler, D. J. 2002. Epidemic dengue/dengue hemorrhagic fever as a public health, social and economic problem for the $21^{\text {st }}$ Century. Trends in Microbiology 10:100-103. http://dx.doi.org/10.1016/S0966-842X(01)02288-0

Gubler, D. J. 2004. The changing epidemiology of yellow fever and dengue, 1900 - 2003: full circle? Comparative Immunology, Microbiology and Infectious Diseases 27:319-330. http://dx.doi.org/10.1016/j.cimid.2004.03.013

Guzman, M. G. and G. Kouri. 2002. Dengue: an update. The Lancet Infectious Diseases 2:33-42. http://dx.doi.org/10.1016/S1473-3099(01)00171-2

Guzman, M. G. and G. Kouri. 2003. Dengue and dengue hemorrhagic fever in the Americas: lessons and challenges. Journal of Clinical Virology 27:1-13. http://dx.doi.org/10.1016/S1386$\underline{6532(03) 00010-6}$

Hanson, H. 1936a. Some observations on dengue. American Journal of Tropical Medicine 16:371375 . 
Hanson, H. 1936b. An epidemic of dengue. American Journal of Public Health 26:256-258. http://dx.doi.org/10.2105/AJPH.26.3.256

Harden, F.W. 1981. You and the environment. Journal of the Florida Anti-Mosquito Association 52:60-61.

Harper, R. M. 1912. Completion of the railroad across the Florida Keys. Bulletin of the American Geographical Society 44:90-93. http://dx.doi.org/10.2307/200217

Heintze, C., M. Velasco Garrido, and A. Kroeger. 2007. What do community-based dengue control programmes achieve? A systematic review of published evaluations. Transactions of the Royal Society of Tropical Medicine and Hygiene 101:317-325. http://dx.doi.org/10.1016/j.trstmh.2006.08.007

Hodge, C. F. 1920. The mosquito-malaria problem in Florida. Florida Entomologist 4:1-6. http://dx.doi.org/10.2307/3492726

Hotez, P. J. 2011. America's most distressed areas and their neglected infections: the United States Gulf Coast and the District of Columbia. PLOS Neglected Tropical Diseases 5(3):e843. http://dx.doi.org/10.1371/journal.pntd.0000843

Kyle, J. A. and E. Harris. 2008. Global spread and persistence of dengue. Annual Review of Microbiology 62:71-92. http://dx.doi.org/10.1146/annurev.micro.62.081307.163005

Lieux, D. B. 1951. Malaria in Florida. Florida Entomologist 34:131-135. http://dx.doi.org/10.2307/3492441

MacDonnell, G. N. 1935. The dengue epidemic in Miami. Journal of the Florida Medical Association 21:392-395.

MacKenzie, J. S., D. J. Gubler, and L. R. Petersen. 2004. Emerging flaviviruses: the spread and resurgence of Japanese encephalitis, West Nile, and dengue viruses. Nature Medicine Supplement 10:S98-S109.

Madden, A. H. 1945. A brief history of medical entomology in Florida. Florida Entomologist 28:17. http://dx.doi.org/10.2307/3492887

McCurdy, J. E. 1963. Mosquitoes and their control in the greater Miami area. American Biology Teacher 25:285-288. http://dx.doi.org/10.2307/4440346

Mulrennan, J. A. 1954. Expanded mosquito control and research in Florida. Florida Entomologist 37:105-111. http://dx.doi.org/10.2307/3492105

Mulrennan, J. A. and W. T. Sowder. 1954. Florida's mosquito control system. Public Health Reports 69:613-618. http://dx.doi.org/10.2307/4588844

Mulrennan, J. A., Jr. 1986. Mosquito control - its impact on the growth and development of Florida. Journal of the Florida Medical Association 73:310-311.

Mulrennan, J.A., Jr. 1991. Benefits of mosquito control. pp. 15-16. In, Mosquito control pesticides: ecological impacts and management alternatives. Proceedings of a conference held on January 18, 1991 at the University of Florida, Gainesville. Scientific Publishers, Inc. Gainesville, Florida, USA. 105 pp.

Patterson, G. 2000. Keep everlastingly at it! Part I: The origins of mosquito control in Florida. Wing Beats Winter 2000:6-8.

Patterson, G. 2004. The Mosquito Wars: A History of Mosquito Control in Florida. University Press of Florida. Gainesville, Florida, USA. 263 pp.

Patterson, G. 2009. The Mosquito Crusades: A History of the American Anti-Mosquito Movement from the Reed Commission to the First Earth Day. Rutgers University Press. Piscataway, New Jersey, USA. 270 pp.

Patterson, K. D. 1992. Yellow fever epidemics and mortality in the United States, 1693-1905. Society, Science, and Medicine 34:855-865. http://dx.doi.org/10.1016/0277-9536(92)90255-O

Pearce, G. F. 1978. Torment of pestilence: yellow fever epidemics in Pensacola. Florida Historical Quarterly 56:448-472.

Pond, W. L., N. J. Ehrenkranz, J. N. Danauskas, and J. E. Davies. 1966. Arboviruses and human disease in South Florida. American Journal of Tropical Medicine and Hygiene 15:205-210.

Porter, J. Y. 1906. Florida. pp. 56-59. In, Transactions of the Fourth Annual Conference of State and Territorial Health Officers with the United States Public Health and Marine-Hospital Service. United States Public Health Service, Washington, DC. 75 pp. 
Provost, M. W. 1973. Environmental quality and the control of biting flies. pp. 1-7. In, Biting fly control and environmental quality. Proceedings of a symposium held at the University of Alberta, Edmonton, May 16-18, 1972. Defence Research Board, Ottawa, Canada. 162 pp.

Radke, E. G., C. J. Gregory, K. W. Kintzinger, E. K. Sauber-Schatz, E. A. Hunsperger, G. R. Gallagher, J. M. Barber, B. J. Biggerstaff, D. R. Stanek, K. M. Tomashek, and C. G. M. Blackmore. 2012. Dengue outbreak in Key West, Florida, USA, 2009. Emerging Infectious Diseases 18:135-137. http://dx.doi.org/10.3201/eid1801.110130

Rigau-Pérez, J. G. 1999. Surveillance for an emerging disease: dengue hemorrhagic fever in Puerto Rico, 1988-1997. Puerto Rico Health Sciences Journal 18:337-345.

Rockefeller Foundation. 1932. The Rockefeller Foundation Annual Report. New York, NY, USA. $455 \mathrm{pp}$.

Roukens, A. H. and L. G. Visser. 2008. Yellow fever vaccine: past, present and future. Expert Opinion on Biological Therapy 8:1787-1795. http://dx.doi.org/10.1517/14712598.8.11.1787

Sanchez, L., V. Vanlerberghe, L. Alfonso, M. del C. Marquetti, M. G. Guzman, J. Bisset,, and P. van der Stuyft. 2006. Aedes aegypti larval indices and risk for dengue epidemics. Emerging Infectious Diseases 12:800-806. http://dx.doi.org/10.3201/eid1205.050866

Scott, T. W. and A. C. Morrison. 2004. Aedes aegypti density and the risk of dengue virus transmission. pp. 187-206. In, Takken W, Scott T. W. (Editors). Ecological aspects for application of genetically modified mosquitoes. Kluwer Academic Publishers. Dordrecht, The Netherlands. 243 pp.

Shaman, J., J. F. Day, and M. Stieglitz. 2004. The spatial-temporal distribution of drought, wetting, and human cases of St. Louis encephalitis in south-central Florida. American Journal of Tropical Medicine and Hygiene 71:251-261.

Shepard, D. S., L. Coudeville, Y. A. Halasa, B. Zambrano, and G. H. Dayan. 2011. Economic impact of dengue illness in the Americas. American Journal of Tropical Medicine and Hygiene 84:200-207. http://dx.doi.org/10.4269/ajtmh.2011.10-0503

Slosek, J. 1986. Aedes aegypti mosquitoes in the Americas: a review of their interactions with the human population. Social Science and Medicine 23:249-257. http://dx.doi.org/10.1016/02779536(86)90345-X

Snyder, F. L. 1993. Nancy Hynes DuVal: Florida's First Lady, 1822 - 1834. Florida Historical Quarterly 72:19-34.

Soper, F. L. 1967. Aedes aegypti and yellow fever. Bulletin of the World Health Organization 36:521-527.

Spencer, R.R. 1922. The anti-plague campaign in Pensacola. The Nation's Health 4:533-536.

Straight, W.M. 1995. Yellow fever at Miami: the epidemic of 1899. Tequesta 55:39-59.

Stroud, H. B. and J. D. Self. 2007. Marco Island: tropical paradise or environmental disaster. Florida Geographer 38:18-32.

Suaya, J. A., D. S. Shepard, and M. E. Beatty. 2007. Dengue: Burden of disease and costs of illness. pp. 35-49 In, Report of the Scientific Working Group meeting on Dengue Geneva, 1-5 October 2006. World Health Organization on behalf of the Special Programme for Research and Training in Tropical Diseases. Geneva, Switzerland. $160 \mathrm{pp}$.

Sudia, W.D., V.F. Newhouse, and W.A. Chappell. 1969. Venezuelan equine encephalitis virusvector studies following a human case in Dade County, Florida, 1968. Mosquito News 29:596600.

Thomas, N. 1981. Presidential address, enemies or allies? Journal of the Florida Anti-Mosquito Association 52:1-3.

Toledo, M. E., A. Rodriguez, L. Valdés, R. Carrión, G. Cabrera, D. Banderas, E. Ceballos, M. Domeqc, C. Peña, A. Baly, V. Vanlerberghe, and P. Van der Stuyft. 2011. Evidence on impact of community-based environmental management on dengue transmission in Santiago de Cuba. Tropical Medicine and International Health 16:744-747. http://dx.doi.org/10.1111/j.1365$\underline{3156.2011 .02762 . \mathrm{x}}$

US Census $\quad$ Bureau. $2010.2010 \quad$ Census. http://factfinder2.census.gov/faces/tableservices/jsf/pages/productview.xhtml?pid=DEC 10 D P DPDP1 Accessed 12 October 2012. 
Vanderblue, H. B. 1927. The Florida land boom. Journal of Land and Public Utility Economics 3:113-131. http://dx.doi.org/10.2307/3138870

Vanlerberge, V., M. E. Toledo, M. Rodríguez, D. Gomez, A. Baly, R. J. Benitez, and P. Van der Stuyft. 2009. Community involvement in dengue vector control: cluster randomized trial. British Medical Journal 338:b1959.

Vickers, E. D. and F. N. Vickers. 1974. Notations on Pensacola's medical history. Journal of the Florida Medical Association 61:83-105.

Viele, J. 1996. The Florida Keys: A History of the Pioneers. Pineapple Press. Sarasota, Florida, USA. Volumes 1-3.

Villari, P., A. Spielman, N. Komar, M. McDowell, and R.E. Timperi. 1995. The economic burden imposed by a residual case of eastern encephalitis. American Journal of Tropical Medicine and Hygiene 52:8-13.

Weller, T. H. 1983. Too few and too little: barricades to the pursuit of health. Review of Infectious Diseases 5:994-1002. http://dx.doi.org/10.1093/clinids/5.6.994

Wilder-Smith, A. and D.J. Gubler. 2008. Geographic expansion of dengue: the impact of international travel. Medical Clinics of North America 92: 1377-1390. http://dx.doi.org/10.1016/j.mcna.2008.07.002

Will, L. E. 1968. Swamp to Sugar Bowl. Great Outdoors Publishing Company. St. Petersburg, Florida, USA. 235 pp.

Williams, L. A., Jr. 1986. The benefits of mosquito control. Journal of the Florida Anti-Mosquito Association 57:32-36.

Work, T. H. 1964. Serologic evidence of arbovirus infection in the Seminole Indians of southern Florida. Science 145: 270-272. http://dx.doi.org/10.1126/science.145.3629.270

Zohrabian, A., M. I. Meltzer, R. Ratard, K. Billah, N. A. Molinari, K. Roy, R. D. Scott II, and L .R. Petersen. 2004. West Nile virus economic impact, Louisiana, 2002. Emerging Infectious Diseases 10:1736-1744. http://dx.doi.org/10.3201/eid1010.030925
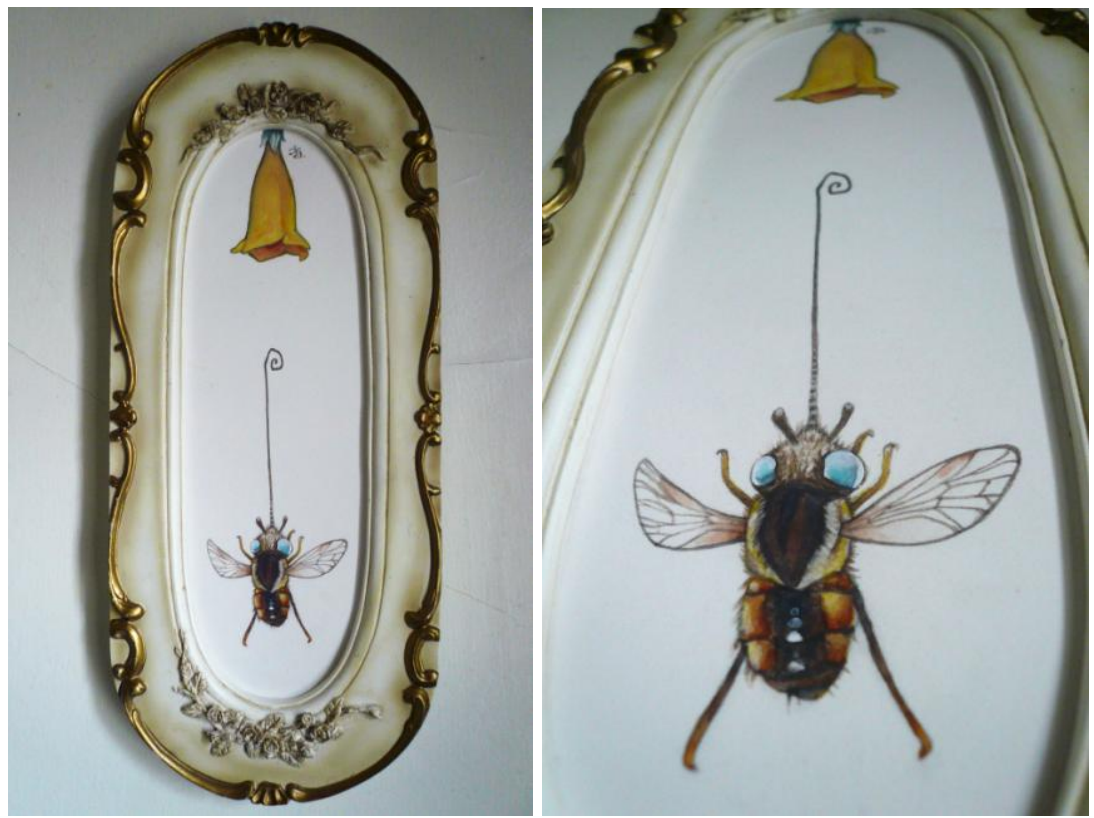

Long tongue fly (left) and detail (right). Copyright by artist, Katie Schuler, who is gratefully acknowledged. 